\title{
Soil classification, suitability assessment, and constraints analyses of major soil series grown to sugarcane in Negros Occidental, Philippines
}

\author{
Clea Anne V. Corsiga ${ }^{1 *}$, Rodrigo B. Badayos² ${ }^{2}$ Pearl B. Sanchez ${ }^{2}$, \\ Erlinda S. Paterno ${ }^{2}$, and Pompe C. Sta. Cruz ${ }^{2}$
}

\begin{abstract}
Five major soil series (Guimbalaon, Isabela, Luisiana, San Manuel, and Silay) in Negros Occidental were evaluated to assess the suitability of major soil series grown to sugarcane and identify possible constraints of the soils for sugarcane production. Specifically, the study assessed the morphological, physical, and chemical properties of soils associated with the growing of sugarcane; evaluated the land quality requirements for major soil series grown to sugarcane; determined the suitability of major soil series for sugarcane production; and evaluated the possible soil constraints to sugarcane production.

Soil pH, total N, percent organic $\mathrm{C}$, and available $\mathrm{P}$ were found highest in Isabela series; exchangeable $\mathrm{K}$ in Guimbalaon series; exchangeable $\mathrm{Na}, \mathrm{Ca}$, and $\mathrm{Mg}$, extractable Fe, and CEC in San Manuel series; and exchangeable Al in Luisiana series. All of the soil series evaluated were classified as marginally suitable (S3) for sugarcane production, although soil constraints varied across soil series. Topography and wetness were the severe constraints common to all soil series. Limitations on fertility and physical soil characteristics were considered moderate and manageable.
\end{abstract}

Keywords: soil classification, soil suitability, soil constraints, sugarcane production

\section{INTRODUCTION}

Sugarcane production is a key economic activity in over 100 countries, particularly in developing countries with high proportion of poor and unemployed groups. As a provider of income and employment, sugarcane-based agriculture has an important role to play in the economic growth of developing economies, especially in the upliftment of financial condition of under-skilled rural people (Meyer et al 2013). The sugarcane industry has expanded enormously over the

' Visayas State University-Villaba, Cagnocot, Villaba, Philippines

${ }^{2}$ University of the Philippines Los Baños, College, Los Baños, Laguna, Philippines

\footnotetext{
* Corresponding Author. Address: Visayas State University-Villaba, Cagnocot, Villaba, Philippines; e-mail: vallejera_19@yahoo.com Mobile:+63-939-551-6923 DOI: $10.32945 /$ atr4015.2018
} 
for ethanol production. Sugarcane production is becoming more concentrated within countries, with the top ten sugarcane-producing countries increasing their share from 56\% in 1980 to around $70 \%$ in 2010 (Meyer et al 2013). The main driver for this expansion is increased world sugar consumption resulting from rising incomes and changes in food consumption patterns, particularly in Asia and Africa (Meyer et al 2013).

Given that more than 20 million hectares of land are cropped to sugarcane mostly as a monoculture, sugarcane production continues to raise concerns about environmental impact and sustainability due to intensive use of agricultural chemicals such as fertilizer, herbicides and ripeners coupled with greater reliance on heavier mechanical harvesters and infield haulage equipment. Sugarcane is listed as one of the four crops to be investigated in terms of its impact on biodiversity as part of the International Finance Corporation's Biodiversity Agricultural Commodities Program (IFC-BACP). It is also widely acknowledged that commercial agriculture such as sugarcane production has the potential to impose severe hydrological, soil degradation, and biodiversity impacts on the natural environment. An estimated 1.5 billion people, or a quarter of the global population, depend directly on land that is being degraded (FAO 2009). Globally, about one tenth of the world's arable area ( 1.2 billion ha) is affected by serious degradation with about $300 \mathrm{~m}$ ha now unusable (UNEP 1997). If agriculture does move to embrace an ecologically-sympathetic approach, the great scientific challenge for the coming years will be to understand more fully the life in our soils and how it may be better managed for food production and environmental renewal (Cribb 2006).

Soil classification arose a long time ago when humans noticed and tried to explain differences in the suitability of soils for different crops (Brady \& Weil 2002). Scientists have developed different systems of soil classification to group soils of similar properties in one class, allowing them to exchange information on soils found in different areas. Soil classification also helps in determining the best possible use and management of soils. This system of classification is strictly qualitative and hierarchical, wherein a soil is classified based on the existence of diagnostic soil horizons and diagnostic soil properties as well as threshold values for measurable soil properties measured up to a maximum soil depth of $200 \mathrm{~cm}$. Hence, classification enables the user to see relationships among and between soils and their environment as well as formulate principles of prediction value (Soil Survey Staff 1951 as cited by Beinroth et al 1978).

The effective and sustainable use of land involves matching site conditions with the specific requirements and potential impacts of different land uses. Significant costs to the environment and society in general may result where land is used for purposes that it is not physically capable of supporting. Suitability analysis is used to determine the appropriateness of a given area for a particular use. The basic premise of suitability analysis is that each aspect of the landscape has intrinsic characteristics that are in some degree either suitable or unsuitable for the activities being planned. It is used extensively to find and maintain good cropland as well as ensure proper crop rotation. Hence, in the process it helps to ensure that land resources are used in the most productive and sustainable ways because different crops require different land types and growing conditions. Consequently, the productive potential of a soil is limited by its inherent 
Soil classification, suitability assessment, and constraints analyses

constraints. Identifying and managing these constraints is fundamental to sustainable production systems.

Generally this study aimed to assess the suitability of major soil series grown to sugarcane in Negros Occidental and identify possible constraints of the soils for sugarcane production using soil classification. Specifically, the study intended to: assess the morphological, physical, chemical, and mineralogical properties of soils associated with the growing of sugarcane; identify the taxonomic classification of major sugarcane soils in Negros Occidental; know the land quality requirements for major soil series grown to sugarcane; determine the suitability of major soil series for sugarcane production; evaluate the possible soil constraints in sugarcane management; and utilize soil classification in soil fertility assessment and fertilizer management.

\section{MATERIALS AND METHODS}

\section{Survey, Assessment and Selection of the Study Sites}

A comprehensive assessment on sugarcane areas was conducted. Topographic, geologic, and soil maps as well as other publications were used as materials in identifying the sampling sites. Major soil series of the province that were mostly grown to sugarcane were identified and utilized in this study. Of the nine soil series that were mostly planted to sugarcane in Negros Occidental, five soil series (Guimbalaon, Luisiana, Isabela, San Manuel, Silay), were comprehensively assessed and utilized in this study since these were the most widespread soil series found in the province (Figure 1).

\section{Soil Data and Climatic Characteristics Collection}

Data on soil and climatic characteristics of the major soil series grown for sugarcane were collected from available references. Simplified Keys to Soil Series of Negros Occidental (PhilRice 2014) and Soil Survey Reports of Negros Occidental (Alicante et al 1951) were used as references for most of the soil characteristics. Climatic characteristics of each soil series were obtained from www.en.climatedata.org.

\section{Suitability Evaluation and Constraint Analyses}

Soil and climatic characteristics of the five soil series (Guimbalaon, Isabela, Luisiana, San Manuel, Silay) were matched with the criteria set by Sys et al (1993) for sugarcane requirements to determine their suitability class. Matching was done using the FAO land evaluation system (FAO 1976) with the following interpretations of suitability classes:

- $\quad 51$ - soils without limitations or with 2 or 3 slight limitations.

- S2 - soils with 2 or 3 slight limitations and no more than 2 moderate limitations.

- $\quad$ S3 - soils with more than 2 moderate limitations and/or no more than 1 severe limitation that however does not exclude the use of the land. 
- $\quad \mathrm{N} 1$ - soils with one severe limitation that excludes the use of the land or more than one severe limitation that can be corrected.

- $\quad \mathrm{N} 2$ - soils with severe or very severe limitations excluding the use of the land and that cannot be corrected.

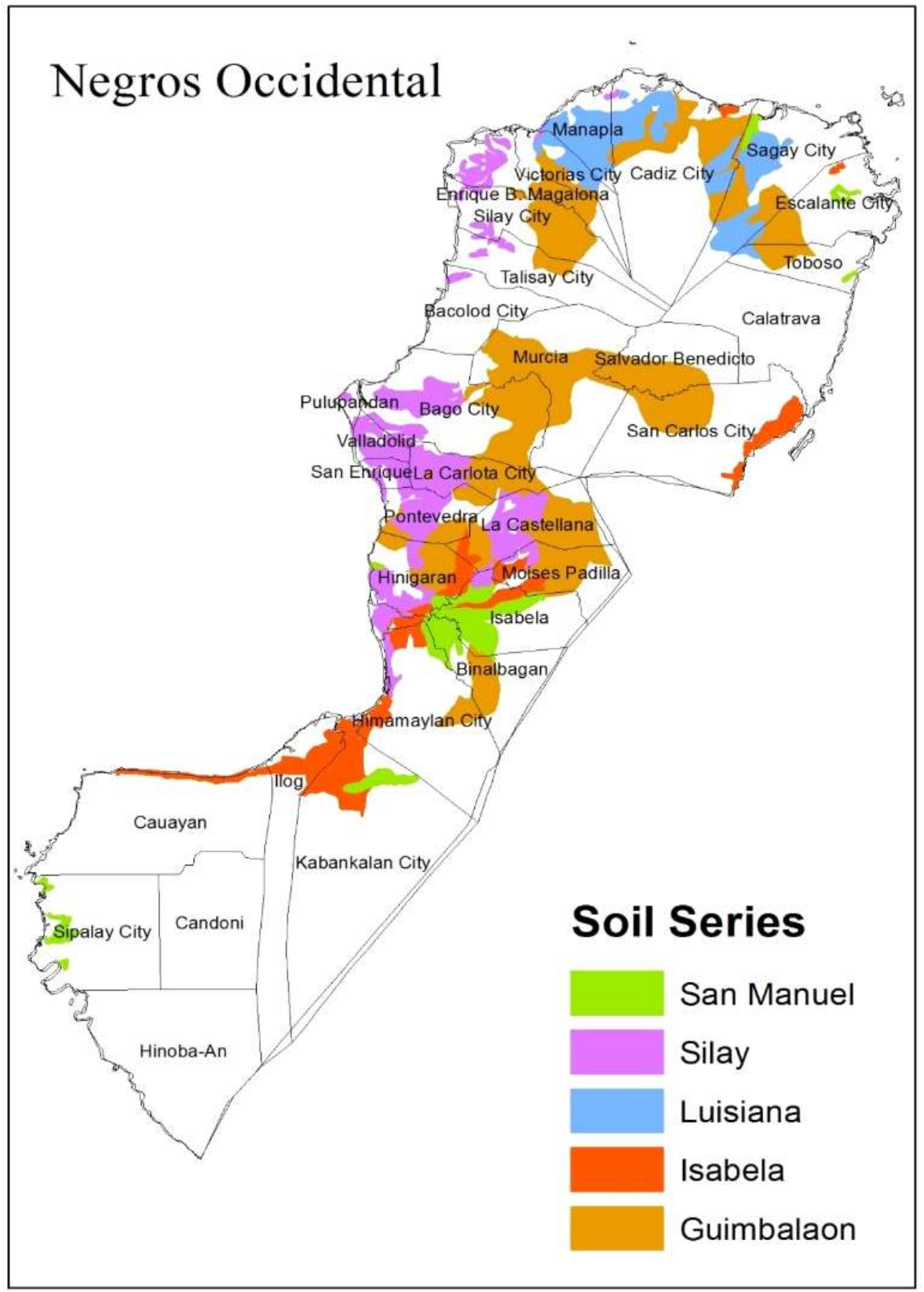

Figure1. Distribution of the five major soil series grown to sugarcane in Negros Occidental 
Soil classification, suitability assessment, and constraints analyses

Accordingly, land suitability indicates whether the land unit is suitable (S) or not suitable $(\mathrm{N})$ for a specified use. Classes spell the degree of suitability. Subclass reflects the kinds of limitation due to topography, soil wetness (flooding and drainage), soil physical properties (texture, coarse fragments and soil depth), soil fertility (apparent $\mathrm{CEC}$, base saturation, and soil $\mathrm{pH}$ ) and climate (annual precipitation and mean monthly temperature). Letter suffixes were assigned to each subclass: " $t$ " for topography, " $w$ " for wetness, " $s$ " for physical properties, " $f$ " for fertility, and " $c$ " for climate. Soil parameters that were identified to limit production after determining the suitability of the soils were considered constraints. Suitability and Constraints Maps were made thereafter.

\section{Soil Collection and Laboratory Analysis}

Twenty soil samples were collected from representative sites and were processed and analyzed in the laboratory for soil $\mathrm{pH}$, total $\mathrm{N}$, available $\mathrm{P}$, exchangeable bases, percent organic carbon, extractable $\mathrm{Fe}$, exchangeable $\mathrm{Al}$, particle size distribution, and cation exchange capacity following standard procedures.

\section{RESULTS AND DISCUSSION}

\section{Morphological, Physical, and Chemical Characteristics of Major Soil Series Grown to Sugarcane}

Buol et al (1997) stated that soil morphology reflects the important properties observed, described, and studied in the field where the soil is in its natural state. The differences in soil characteristics associated with landscape position are usually attributed to differences in the runoff, erosion, and deposition processes which affect soil genesis (Canton et al 2003, Dengiz 2010). Hence, assessment of the potentials and limitations of soil for the different land uses provides the basis for formulating the appropriate management strategies which target specific management problems to improve crop production and soil and water conservation strategies (Karuma et al 2015).

Five major soil series namely Guimbalaon, Luisiana, Isabela, San Manuel, and Silay grown to sugarcane in Negros Occidental were assessed. These five soil series were described in the Simplified Keys to Soil Series Guidebook (PhilRice 2014). Guimbalaon soil was formed from older alluviums, which are country rocks and washed out materials from the upper slopes. It is described as a young soil in its incipient development stage but has not yet fully developed its diagnostic horizons. Isabela soil was formed from alluvial deposits and is described as an old soil with high base status and alluvial accumulation of clay in the subsoil horizons from underlying horizons that exhibits minimum complexity in its horizonation. Luisiana soil developed from highly weathered basaltic volcanicro ck materials and is described as a highly leached old soil with accumulation of clay in the lower horizon and has low base status. San Manuel soil is a non-calcareous soil that formed in recent water-deposited sediments mainly in flood plains which are frequently subjected to flooding. Silay soil is described as a fine loamy-textured soil with more than $15 \%$ fine sand including gravels and $18-35 \%$ clay composed of different minerals (mixed). 
Based on the results of the soil chemical analyses of the different soil series, Isabela series obtained the highest value on $\mathrm{pH}$ (both in $\mathrm{H}_{2} \mathrm{O}$ and $\mathrm{CaCl}_{2}$ ), total nitrogen, percent organic carbon, and available phosphorus among other soil series. Exchangeable $\mathrm{K}$ was found to be highest in Guimbalaon series while exchangeable $\mathrm{Na}, \mathrm{Ca}, \mathrm{Mg}$ as well as extractable $\mathrm{Fe}$ and cation exchange capacity were highest in San Manuel series. Exchangeable Al was highest in Luisiana series as compared to other soil series. However, Luisiana series was found to be low in most of the chemical properties evaluated in the soil pH in both in $\mathrm{H} 2 \mathrm{O}$ and $\mathrm{CaCl}$, percent total $\mathrm{N}$, exchangeable $\mathrm{K}, \mathrm{Na}, \mathrm{Ca}$, and $\mathrm{Mg}, \mathrm{CEC}$, and extractable Fe while Silay series were low in percent organic carbon, available $P$ and Isabela series for exchangeable Al. Morphological, physical, and chemical characteristics of these soils are shown in Table 1.

\section{Land Qualities/Land Characteristics of Major Soil Series Grown to Sugarcane}

According to Sys et al (1991), land characteristics are measurable properties of the physical environment directly related to land use while land qualities are measurable, calculable, or estimable attributes, representing the immediate requirements of the land utilization types and are in fact the consequences of land characteristics. In addition, both land characteristics and land qualities influence the suitability of land that will depend on the fact whether some of these characteristics/qualities are optimal, marginal, or suitable. Therefore, evaluation of characteristics and qualities, for specific land use, is an essential stage in the overall evaluation work (Sys et al 1991). The summary of the land characteristics of major soil series, namely, Guimbalaon, Isabela, Luisiana, San Manuel, and Silay are presented in Table 2.

\section{Land Quality Requirements of Sugarcane}

Land Quality Requirements can be synthesized from the analysis of the behavior of crop yields as influenced by temperature, moisture regime, and soil properties including effective rooting depth, texture, internal drainage, $\mathrm{CEC}, \mathrm{pH}$, and salinity.

In this study, the land quality requirement of sugarcane was analyzed. The standard crop requirement information was based on Land Evaluation of Sys et al (1993) involving climate, landscape, and soil conditions. The evaluation applies the information on topography (t), wetness (w), physical soil characteristics (s), soil fertility characteristics ( $f$ ), and climate (c) of the different major soil series under study. Each parameter measured for the different soil series were rated as highly suitable (S1), moderately suitable (S2), marginally suitable (S3), currently not suitable (N1), and permanently not suitable (N2). Land suitability classes were made thereafter as shown in table 3 . Based on the results, the soil series have different suitability with respect to the different parameters mentioned. Results revealed that all soil series namely Guimbalaon, Isabela, Luisiana, San Manuel, and Silay were classified as marginally suitable (S3); however, limitation for sugarcane production varies in each soil series. A suitability map was then prepared (Figure 2). Soils that were not studied and found in the map were indicated as others. 
Soil classification, suitability assessment, and constraints analyses

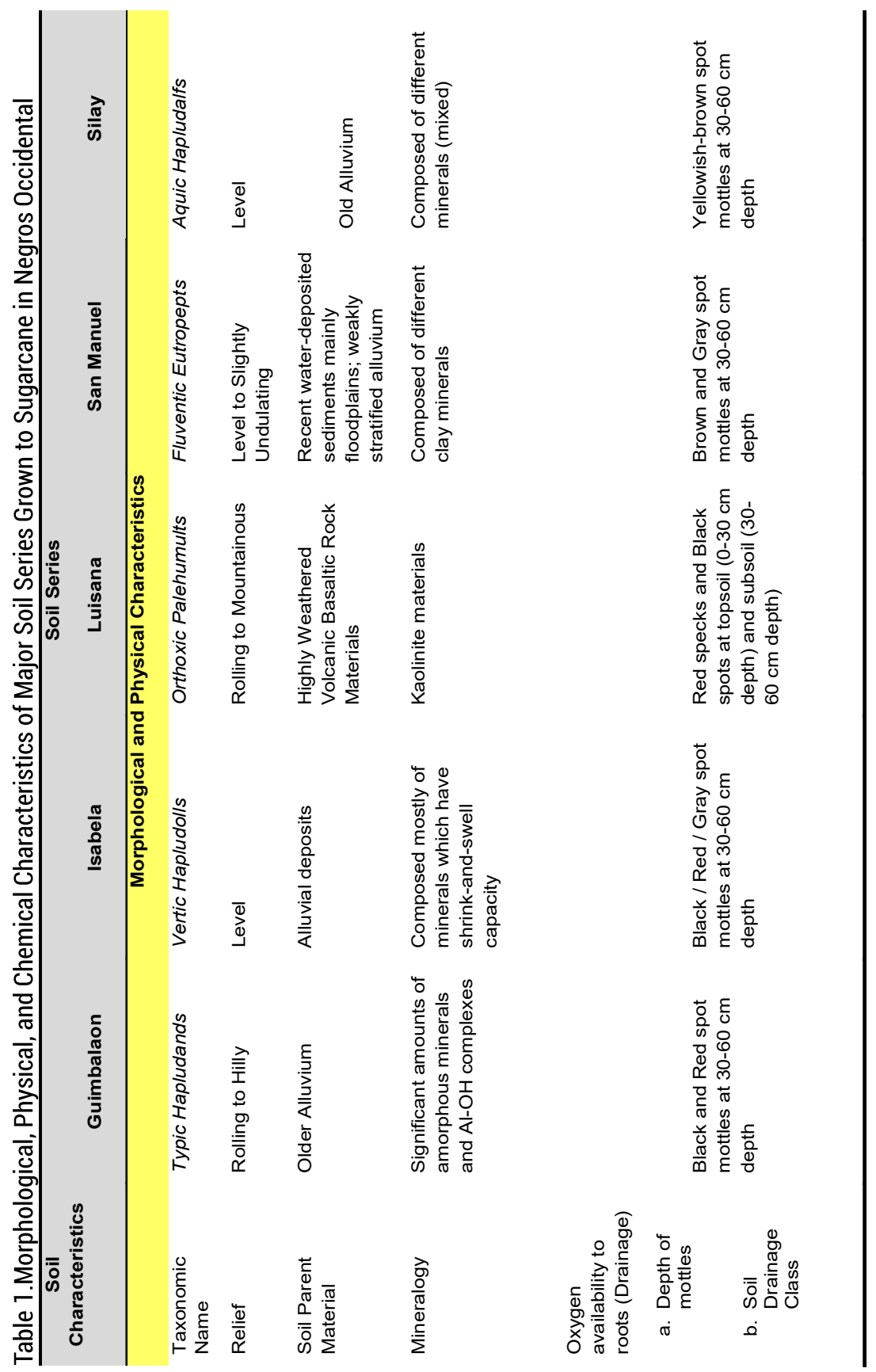


Corsiga et al

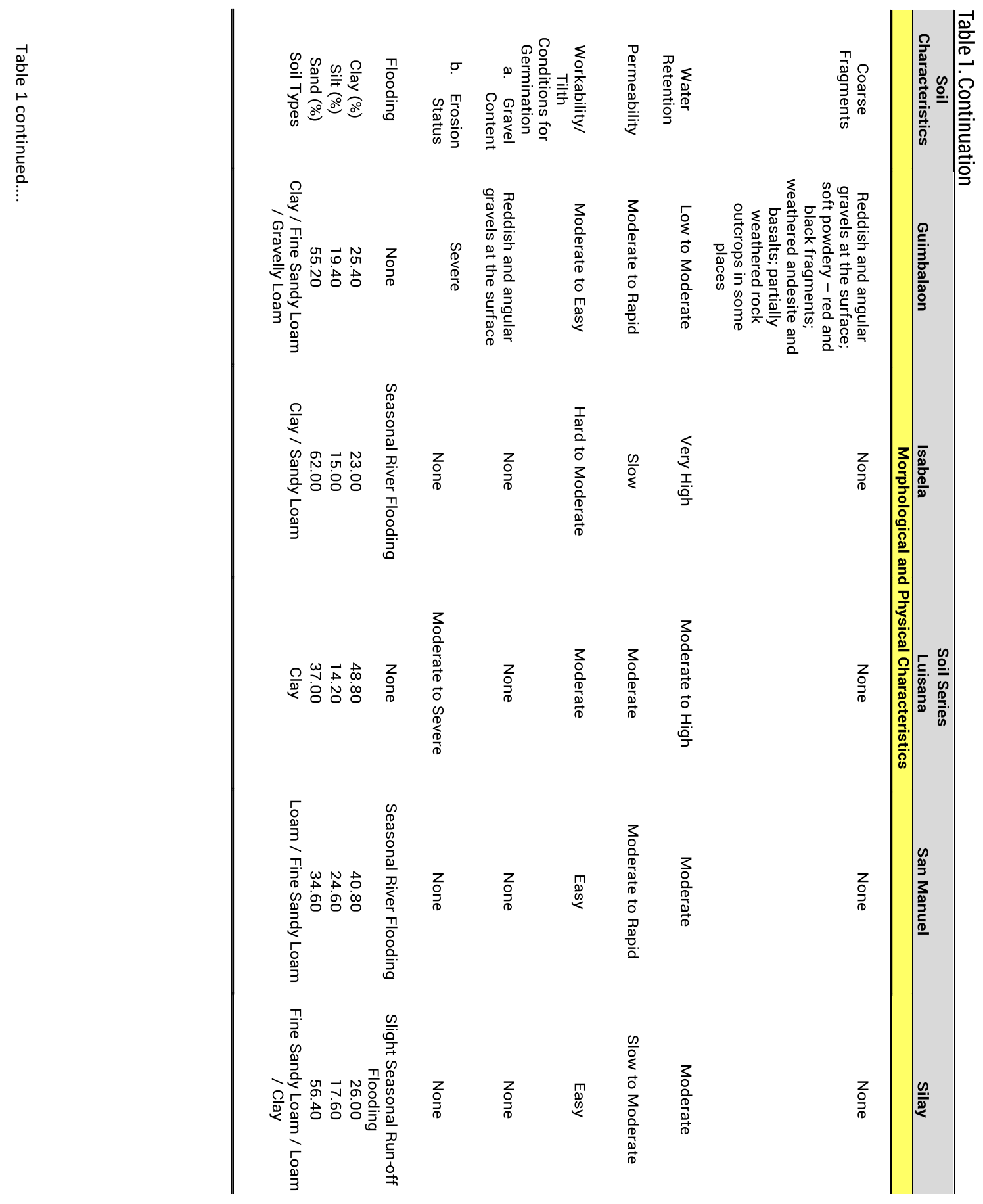


Soil classification, suitability assessment, and constraints analyses

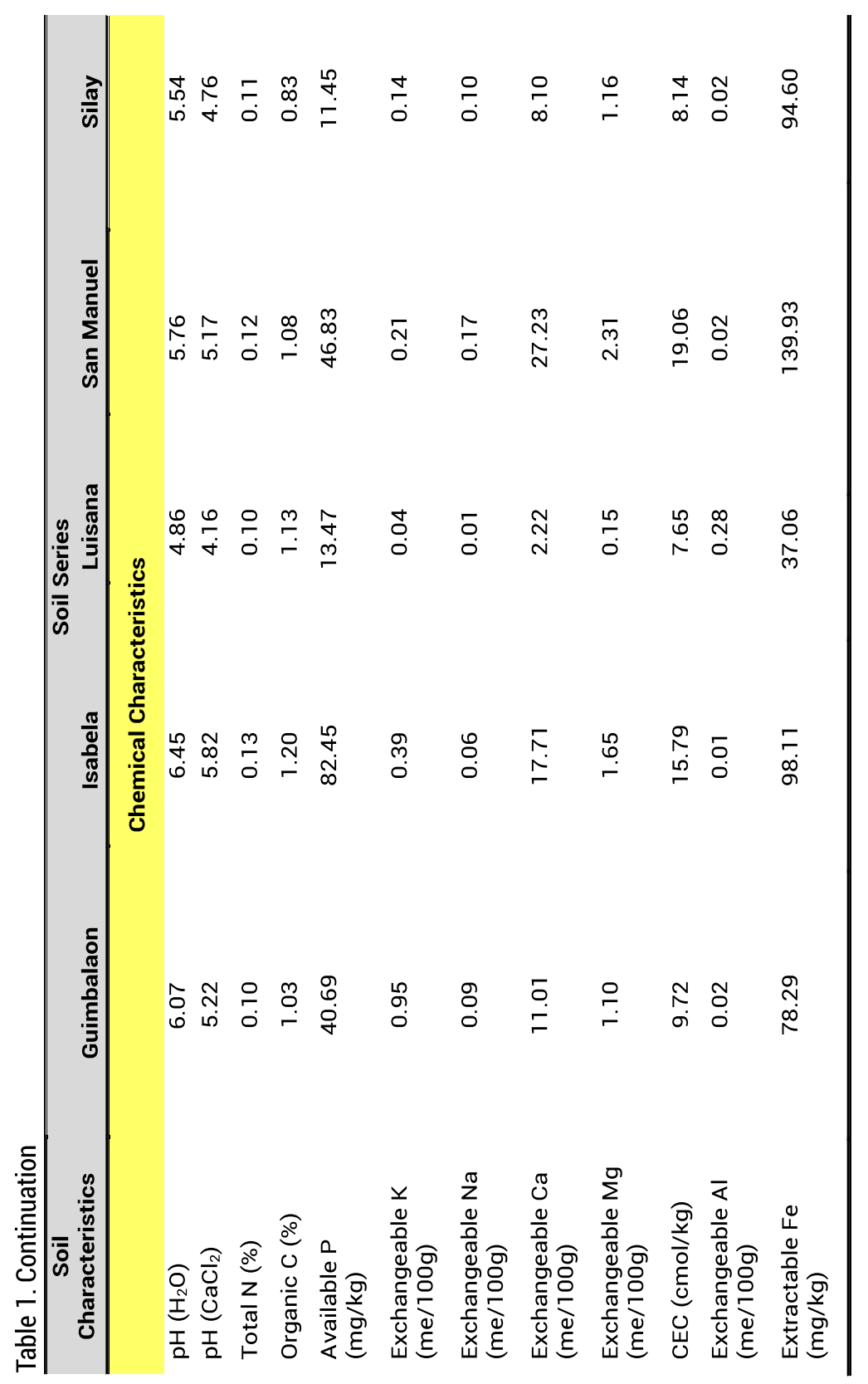


Corsiga et al

\begin{tabular}{|c|c|c|c|c|c|c|}
\hline$\stackrel{\mathscr{O}}{\stackrel{\mathscr{P}}{\mathscr{N}}}$ & 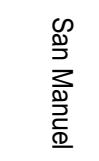 & $\frac{\bar{c}}{\frac{\bar{c}}{\bar{w}}}$ & $\begin{array}{l}\bar{\Phi} \\
\frac{\mathbb{N}}{\bar{D}} \\
\frac{\Phi}{\omega}\end{array}$ & 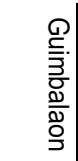 & 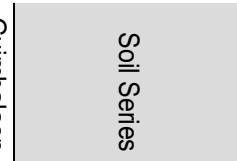 & \\
\hline $\begin{array}{l}0 \\
\dot{n}\end{array}$ & $\begin{array}{l}\text { í } \\
\text { ír }\end{array}$ & $\begin{array}{l}\vec{\infty} \\
1 \\
\sim\end{array}$ & $\begin{array}{l}0 \\
\dot{N}\end{array}$ & $\begin{array}{c}\overrightarrow{0} \\
0 \\
1 \\
0\end{array}$ & $\frac{C}{\circ}$ & \\
\hline 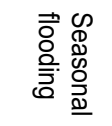 & 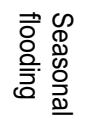 & ๖. & 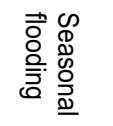 & $\begin{array}{l}\text { z } \\
\text { के }\end{array}$ & $\begin{array}{l}\frac{7}{\overline{0}} \\
\frac{\circ}{\overline{0}}\end{array}$ & \\
\hline 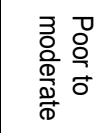 & $\stackrel{8}{\circ}$ & 8 & 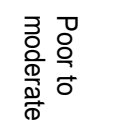 & 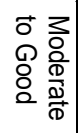 & 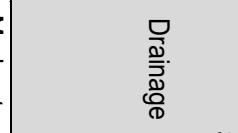 & \\
\hline 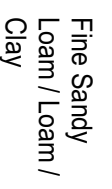 & 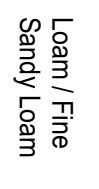 & $\stackrel{\bigcirc}{\stackrel{\varrho}{\aleph}}$ & 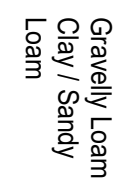 & 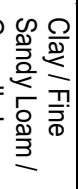 & 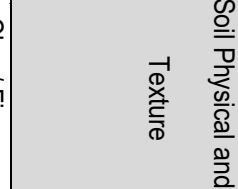 & 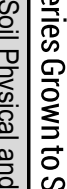 \\
\hline$\frac{\text { z }}{\stackrel{\varpi}{0}}$ & $\frac{\text { o }}{\text { o }}$ & ż & zo. & $=$ & 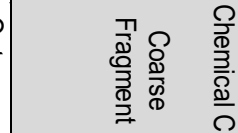 & 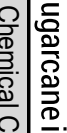 \\
\hline 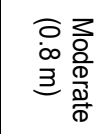 & 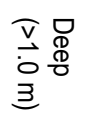 & 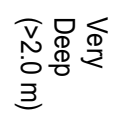 & 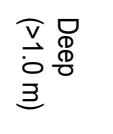 & 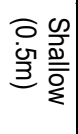 & 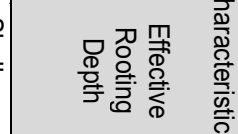 & 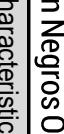 \\
\hline $\begin{array}{l}w \\
\stackrel{w}{N} \\
\text { o } \\
o r\end{array}$ & ثै & $\begin{array}{l}\vec{D} \\
\tilde{\sigma}\end{array}$ & $\begin{array}{r}\overrightarrow{0} \\
\stackrel{0}{0} \\
0\end{array}$ & $\begin{array}{l}A \\
\text { ज़ } \\
8\end{array}$ & 종 & \\
\hline $\begin{array}{l}\overrightarrow{\vec{\infty}} \\
\stackrel{\omega}{\omega}\end{array}$ & $\begin{array}{l}\text { जे } \\
\text { 항 }\end{array}$ & $\underset{\substack{\omega \\
\stackrel{\omega}{G}}}{\stackrel{\omega}{\leftrightarrows}}$ & $\begin{array}{l}\vec{\omega} \\
\text { 惢 } \\
0\end{array}$ & $\begin{array}{l}\vec{\omega} \\
\dot{\omega} \\
\infty\end{array}$ & 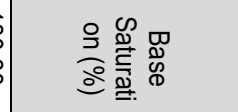 & \\
\hline 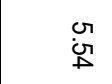 & ๙̋ & $\stackrel{+}{\dot{\infty}}$ & $\begin{array}{l}\text { Oे } \\
\text { जे }\end{array}$ & $\ddot{\theta}$ & 호 & \\
\hline 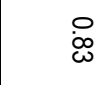 & $\overrightarrow{\dot{\infty}}$ & $\overrightarrow{\vec{\omega}}$ & $\overrightarrow{\tilde{\sigma}}$ & & 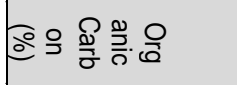 & \\
\hline$\stackrel{\sim}{\unlhd}$ & $\underset{N}{N}$ & $\underset{D}{N}$ & $\underset{\omega}{\sim}$ & $\begin{array}{l}\sim \\
\tilde{O} \\
0\end{array}$ & \multirow{3}{*}{\multicolumn{2}{|c|}{ 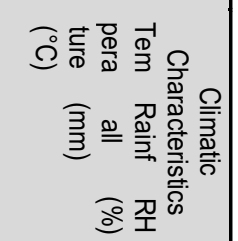 }} \\
\hline$\stackrel{N}{N}$ & $\underset{\sim}{\stackrel{N}{W}}$ & $\stackrel{N}{\text { ज़ }}$ & 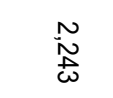 & $\begin{array}{c}\tilde{N} \\
\vec{\omega}\end{array}$ & & \\
\hline 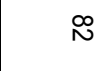 & $\stackrel{\infty}{\sim}$ & $\stackrel{\infty}{\sim}$ & $\stackrel{\infty}{N}$ & $\stackrel{\infty}{N}$ & & \\
\hline
\end{tabular}


Soil classification, suitability assessment, and constraints analyses

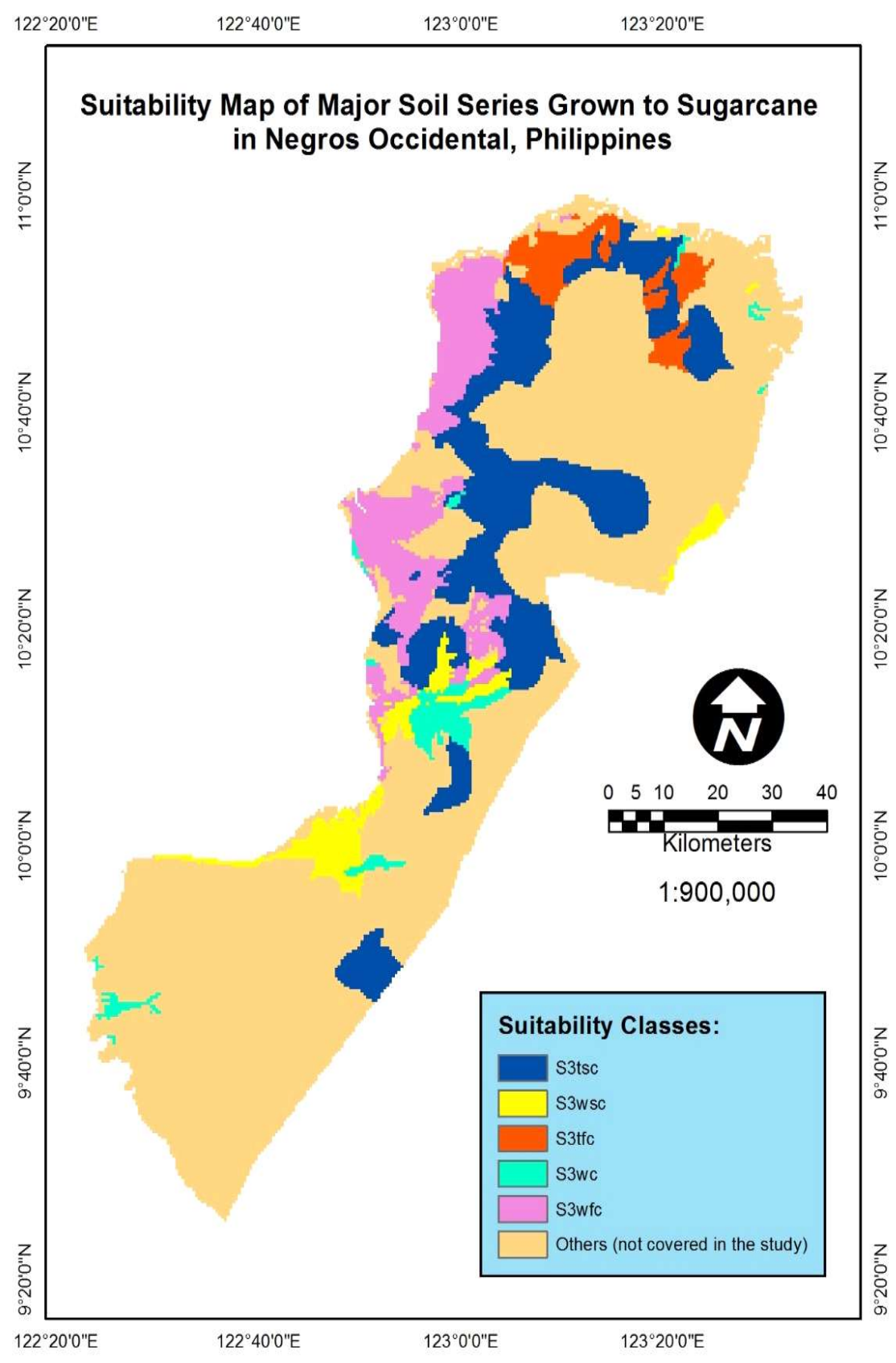

Figure 2. Suitability Map of Major Soil Series Grown to Sugarcane in Negros 
Corsiga et al

\section{Crop Constraints Analysis}

The use of land limitations is a way of expressing the land characteristics or land qualities in a relative evaluation scale. Limitations are deviations from the optimal conditions of a land characteristics/land quality which adversely affect a kind of land-use (Sys et al 1991). The suitability ratings (Table 3) were utilized in the determination of the limitations or constraints of the crop from the different soil series under study. Based on the results, topography and wetness are the severe constraints for most of the soils. The influence of landscape on agricultural land use is multiple. Topography or relief is the expression of the interaction of the several different phenomena and processes within the earth's crust and on its surface. Its form and dimensions are primarily related to geological formations and to the climate, both past and present, which have either directly or indirectly acted upon these formations. On the other hand, wetness situation of a land unit is defined by drainage and flooding. Drainage is considered in almost every system of land capability classification. For instance, the suitability for upland crops decreases when drainage conditions become impeded. Likewise, flooding is also considered a serious limitation (Sys et al 1991).

Nevertheless, climate specifically relative humidity $(\mathrm{RH})$ was observed to be the common factor for all soil series which moderately limited production of sugarcane since it had exceeded the maximum requirement of humidity needed by the crop. At specific crop development stages, a too high relative humidity may affect susceptibility to diseases. A too low relative humidity at seed formation may cause shrinkage of seeds and lower yields (Sys et al 1991).

Other factors noted were physical soil characteristics and fertility; however, limitation is moderate and manageable. Table 4 presents the summary of constraints of the major soil series for sugarcane production. Isabela, San Manuel, and Silay series have problems on wetness due to its seasonal flooding occurrences (Table 2). On the other hand, Guimbalaon and Luisiana series have constraint on topography because of its rolling to hilly to mountainous topographic position (Table 2). A constraints map is presented in Figure 3. 
Soil classification, suitability assessment, and constraints analyses

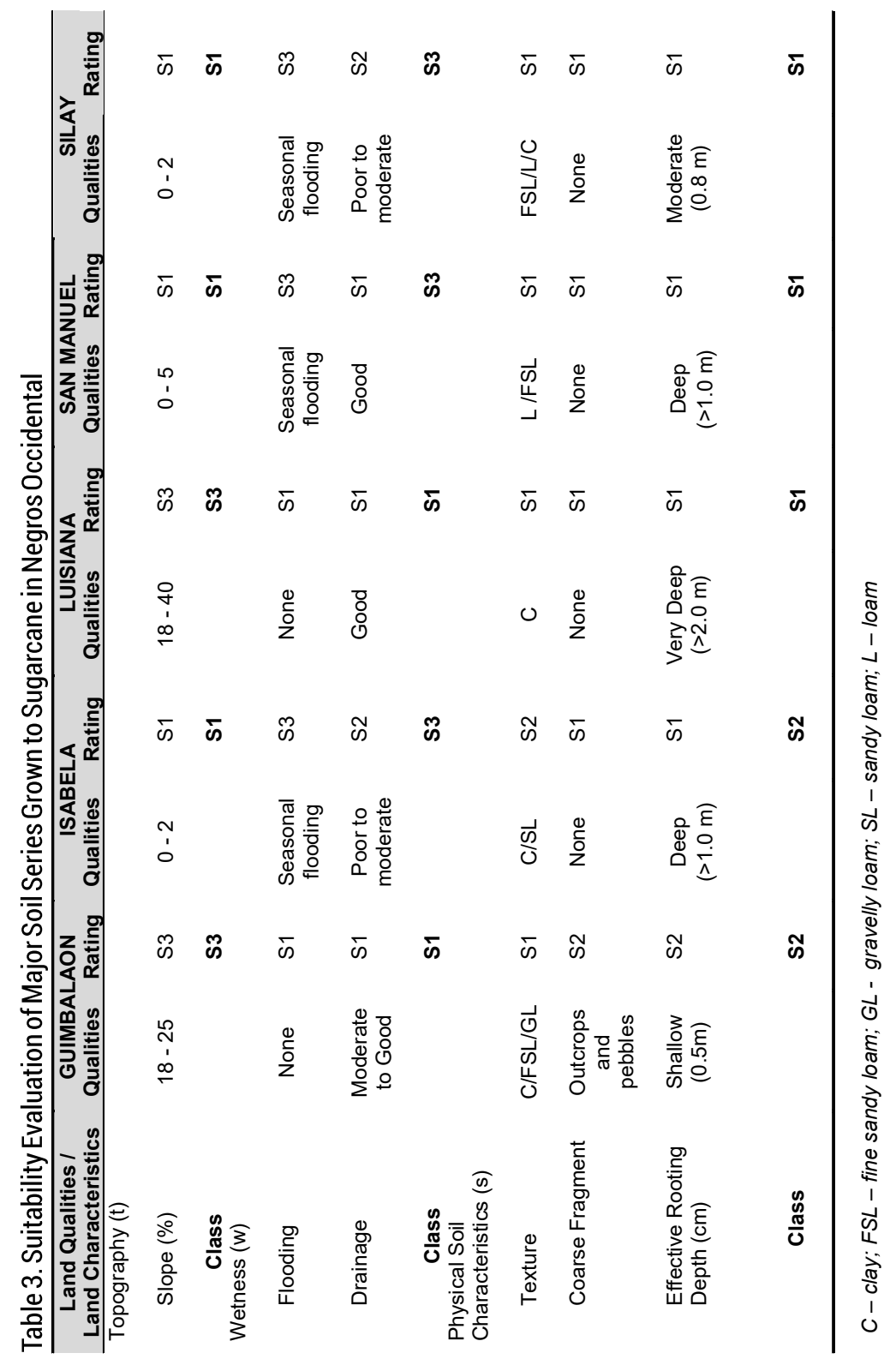




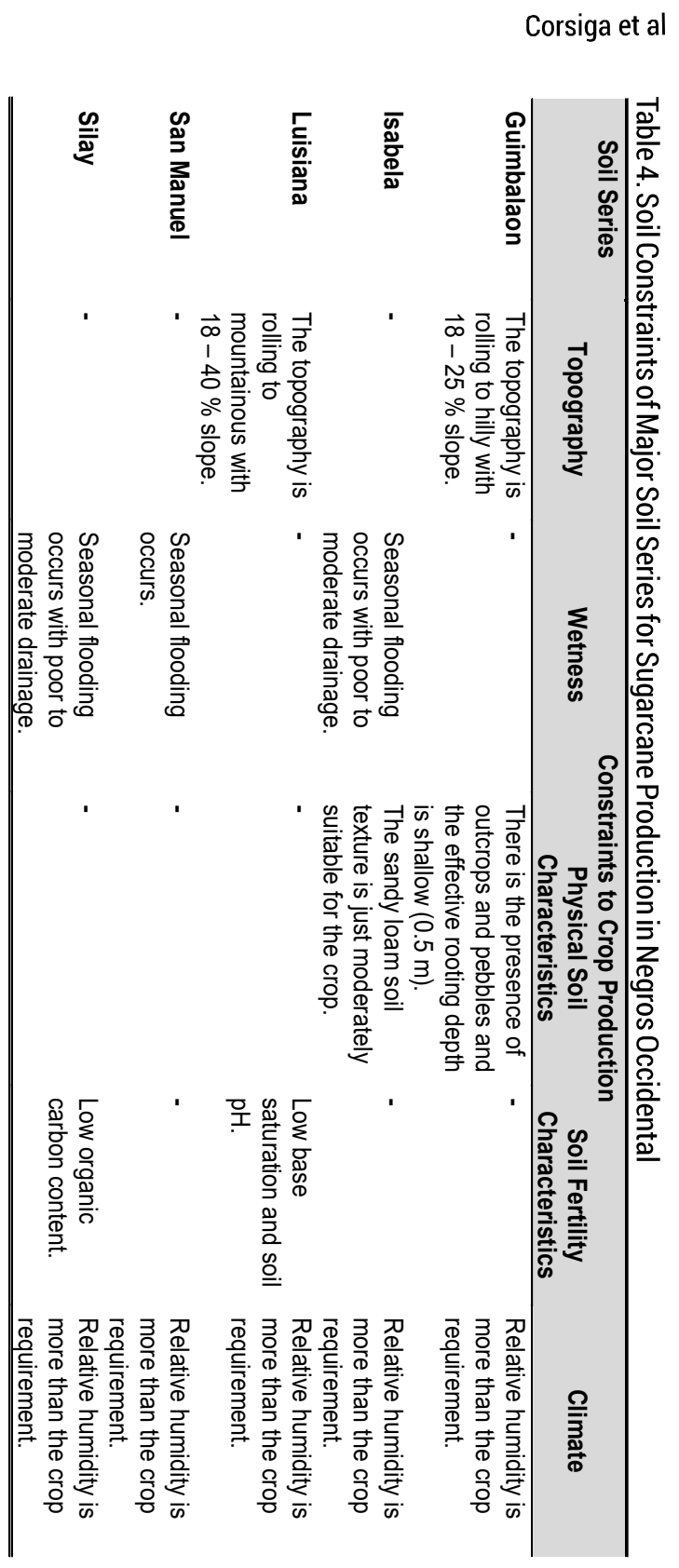


Soil classification, suitability assessment, and constraints analyses

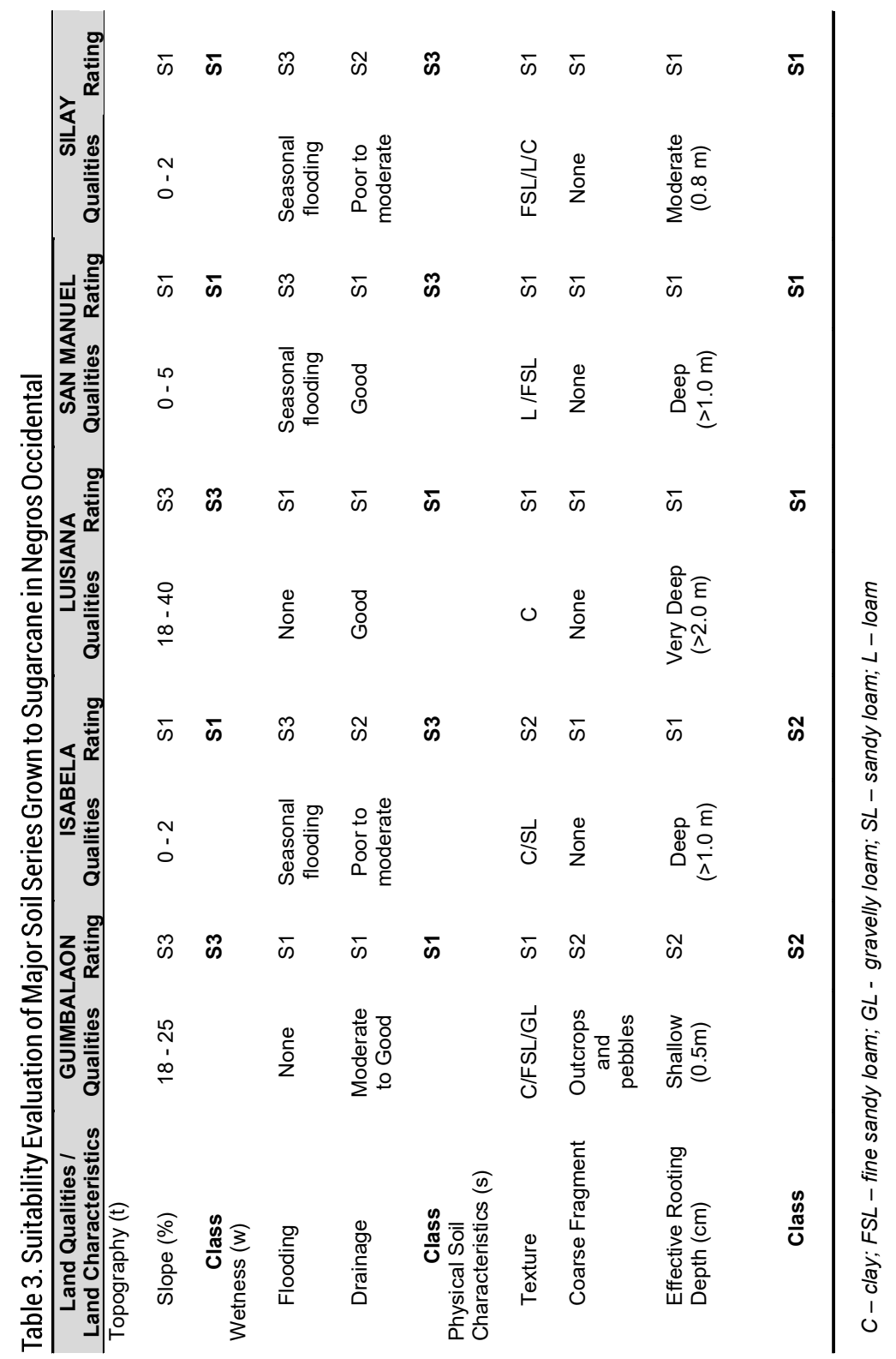




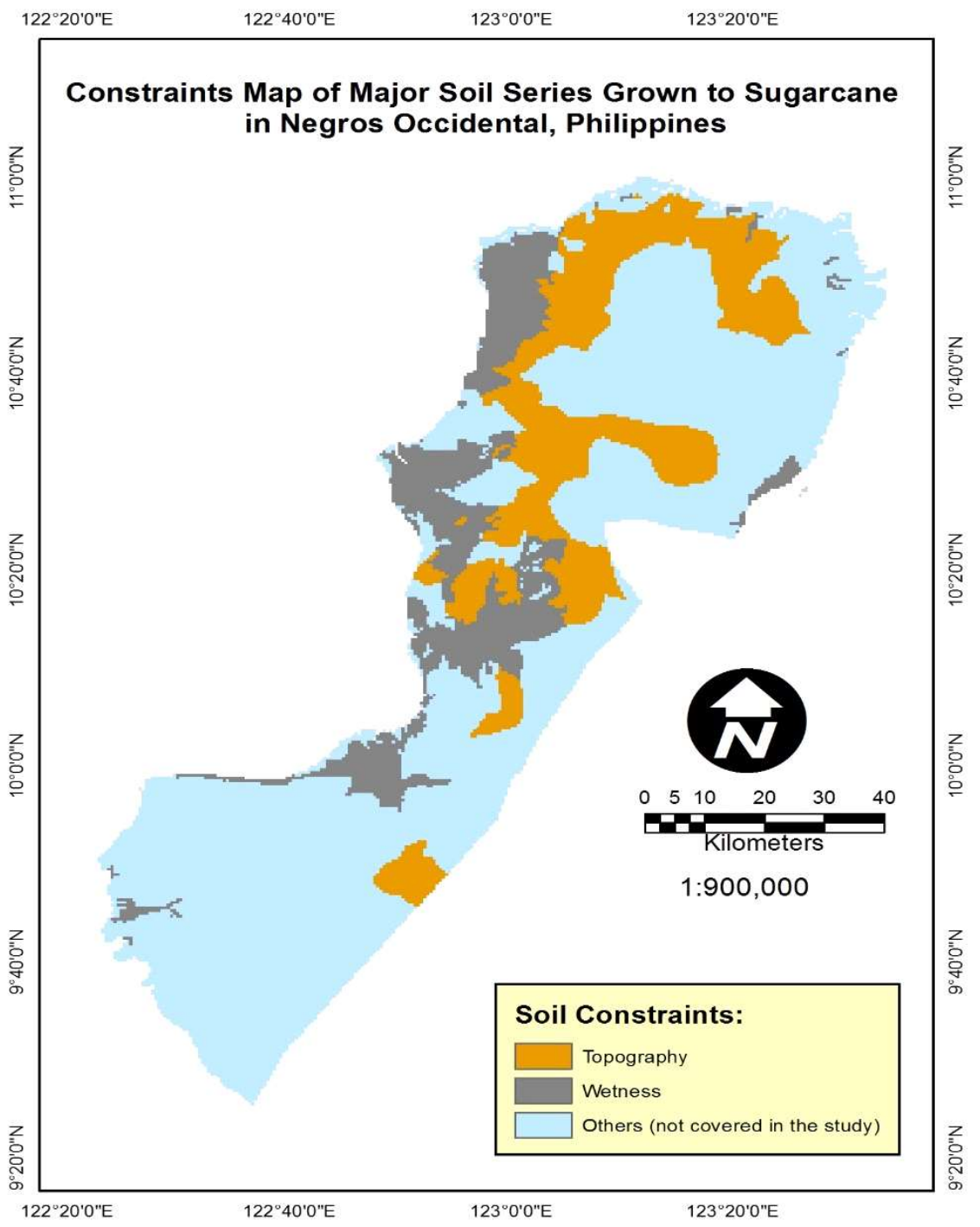

Figure 3. Constraints Map of Major Soil Series Grown to Sugarcane in Negros

\section{CONCLUSIONS}

Five major soil series (Guimbalaon, Isabela, Luisiana, San Manuel, and Silay) that were widely planted to sugarcane in Negros Occidental possess different morphological, physical, and chemical characteristics due to different soil factors (parent materials, topography, climate, living organisms, time) that affect soil genesis. Guimbalaon series, derived from older alluvium and described as young soil, have high exchangeable K. Isabela series, formed from alluvial deposits and 
described as an old soil with high base status, obtained the highest chemical value on $\mathrm{pH}$ (both in $\mathrm{H}_{2} \mathrm{O}$ and $\mathrm{CaCl}_{2}$ ), total nitrogen, percent organic carbon, and available phosphorus among other soil series. Luisiana soil, developed from highly weathered basaltic volcanic rock materials and described as a highly leached old soil, was high in exchangeable Al. San Manuel series, a non-calcareous soil that formed in recent water-deposited sediments mainly in flood plains, was highest in exchangeable $\mathrm{Na}, \mathrm{Ca}, \mathrm{Mg}$ as well as extractable $\mathrm{Fe}$ and cation exchange capacity. Silay series, a fine loamy-textured soil which was derived from mixed mineral materials of more than $15 \%$ fine sand including gravels and $18-35 \%$ clay, was found to be low in percent organic carbon and available P. s. Letters in Applied Microbiology, 48:705-711.

Guimbalaon, Isabela, Luisiana, San Manuel, and Silay soil series were classified as marginally suitable (S3) for sugarcane production although, soil constraints varied across soil series. Topography and wetness were the severe constraints for most of the soils; however, limitation for fertility and physical soil characteristics were considered moderate and manageable.

\section{ACKNOWLEDGMENT}

This research was funded by the DOST-Accelerated Science and Technology Human Resource Development Program (ASTHRDP) NSC and the Student Research Support Fund through DOST SEI.

\section{REFERENCES}

Alicante MM, Rosell DZ, Barrera A, Jaug JO \& Engle L. 1951. Soil survey report of Negros Occidental Province, Phillipines. Department of Agriculture and Natural Resources, Manila.

Beinroth FH. 1978. Some fundamentals of soil classification. In Leslie D. Swindale LD (ed), Soil-resource data for agricultural development. Hawaii Agricultural Experiment Station, College of Tropical Agriculture, University of Hawaii.

Brady NC and Weil RR. 2002. The nature and properties of soil ( $13^{\text {th }}$ edn). Prentice Hall, Upper Saddle River, NJ.

Buol SW, Hole FD, McCracken RJ \& Southard RJ. 1997. Soil Genesis and Classification (4th edn). lowa State University Press, Ames.

Canton Y, Bent AS \& Lazaro R. 2003. Soilgeomorphology relations in gypsiferour materials of the Tabernas Desert. Geoderma, 115:193-222

Cribb J. 2006. Can Australian soil science save the world? Keynote address at the ASSSI-ASPACACMS National Soils Conference, Adelaide.

Dengiz 0. 2010. Morphology, physico-chemical properties and classification of soils on terraces of the Tigris River in the South-east Anatolia Region of Turkey. JfAgricultural Sciences, 16:205-212.

Food and Agriculture Organization. 2009. Land degradation as ses sment i $n$ the dryland areas. A c c e s s e d f o m http://www.fao.org/nr/lada/index.php?/News/

Latest/GLADA-preliminary.html

Food and Agriculture Organization. 1976. A Framework for Land Evaluation. Soils 
Karuma ANC, Gachene KK, Msanya BM, Mtakwa PW, Amuri N \& Gicheru PT.2015. Soil morphology, physico-chemical properties and classification of typical soils of Mwala District,Kenya. International J Plant \& Soil Science, 4(2):156170, 2015; Article no.IJPSS.2015.017 ISSN: 2320-7035

Zimand G, Elad I \& Chet I. 1996. Effect of Trichoderma harzianum on Botrytis cinerea pathogenicity. Phytopathology, 86:1255-1260.

Meyer J, Rein R, Turner P \& Mathias K. 2013. Good management practices manual for the cane sugar industry. International Finance Corporation. PGBI House, 8 Wolseley Street, Woodmead East, 2191, Johannesburg, South Africa.

Philippine Rice Research Institute. 2014. Simplified keys to soil series: Negros Occidental. Maligaya, Science City of Munoz, Nueva Ecija.

Sys C, Ranst EV, Debaveye J \& Beernaert F. 1993. Land Evaluation: Part III-Crop Requirements. General Administration for Development Cooperation, Belgium.

Sys C, Ranst EV, Debaveye J \& Beernaert F. 1991. Land Evaluation: Part I-Principles in Land Evaluation and Crop Production Calculations. General Administration for Development Cooperation, Belgium.

United Nations Environment Programme (UNEP). 1997. Looking to the future. In Global Environmental Outlook. Accessed from http://www.unep.org/Geo/geo 1/ch/ch4_11.htm 